\title{
Pola bakteri aerob pada sputum penderita infeksi saluran pernapasan akut di Poliklinik Paru RSUP Prof. Dr. R. D. Kandou Manado
}

\author{
${ }^{1}$ Oktafin N. Manggopa \\ ${ }^{2}$ Standy Soeliongan \\ ${ }^{2}$ Heriyannis Homenta
}

\author{
${ }^{1}$ Kandidat Skripsi Fakultas Kedokteran Universitas Sam Ratulangi, Manado \\ ${ }^{2}$ Bagian Mikrobiologi Fakultas Kedokteran Universitas Sam Ratulangi, Manado \\ Email: nmanggopa11_197@yahoo.com
}

\begin{abstract}
Upper and lower respiratory tract infections are commonly found in the community. This study aimed to determine the pattern of aerobic bacteria in the sputum of acute respiratory infection patients at the Clinic of Lung Diseases Prof. Dr. R. D. Kandou Hospital Manado. This was an experimental laboratory study. There were 20 respondents consisted of 15 males (75\%) and 5 females (25\%). Bacteria were stained with Gram staining. The results of sputum examination were 12 samples (60\%) of Gram-positive bacteria and 8 samples (40\%) of Gram-negative bacteria. The Gram-positive bacteria consisted of two species: Bacillus subtillis in 10 samples (50\%), and Streptococcus sp in 2 samples (10\%). Moreover, the Gramnegative bacteria consisted of 7 species: Enterobacter chloacae in 1 sample (5\%), Proteus alcalifaciens in 1 sample (5\%), Yersinia pestis in 1 sample (5\%), Enterobacter agglomerans in 2 samples (10\%), Serratia marcessens in 1 sample (5\%), Serratia rubidaea in 1 sample (5\%), and Serratia liquefaciens in 1 sample (5\%). Conclusion: The most common cause of acute respiratory bacterial infections was Bacillus subtilis.
\end{abstract}

Keywords: acute respiratory disease, aerobic bacteria

\begin{abstract}
Abstrak: Infeksi saluran pernapasan atas dan bawah merupakan penyakit yang umum terjadi di masyarakat. Penelitian ini bertujuan untuk mengetahui pola bakteri aerob pada sputum penderita infeksi saluran pernapasan akut (ISPA) di Poliklinik Paru RSUP Prof. Dr. R. D. Kandou Manado. Jenis penelitian ini eksperimental laboratorium. Terdapat 20 responden yang terdiri dari 15 orang laki-laki (75\%) dan 5 orang (25\%) perempuan (25\%). Untuk identifikasi bakteri dalam sputum digunakan pewarnaan Gram. Hasil pewarnaan Gram yaitu bakteri Gram positif 12 sampel (60\%) sedangkan bakteri Gram negatif 8 sampel (40\%). Bakteri Gram positif terdiri dari 2 spesies yaitu Bacillus subtillis 10 sampel (50\%) dan Streptococcus sp. 2 sampel (10\%). Bakteri Gram negatif terdiri dari 7 spesies yaitu Enterobacter chloacae 1 sampel (5\%), Proteus alcalifaciens 1 sampel (5\%), Yersinia pestis 1 sampel (5\%), Enterobacter agglomerans 2 sampel (10\%), Serratia marcessens 1 sampel (5\%), Serratia rubidaea 1 sampel (5\%), dan Serratia liquefaciens 1 sampel (5\%). Simpulan: Pada penelitian ini didapatkan bakteri penyebab terbanyak ISPA pada pasien di poliklinik paru ialah Bacillus subtilis.
\end{abstract}

Kata kunci: infeksi saluran napas akut, bakteri aerob

Infeksi saluran pernapasan merupakan penyakit yang umum terjadi pada masyarakat. Infeksi saluran pernapasan berdasarkan wilayah infeksinya terbagi menjadi infeksi saluran pernapasan atas dan infeksi saluran pernapasan bawah. Umumnya, penyebab infeksi saluran napas ialah berbagai mikroorganisme, namun yang terbanyak yakni oleh karena infeksi virus dan bakteri. ${ }^{1,2}$ 
Perhimpunan Dokter Paru Indonesia menyatakan bahwa penyakit infeksi saluran napas bawah menempati urutan kedua sebagai penyebab kematian tertinggi di masyarakat berdasarkan hasil Survei Kesehatan Rumah Tangga Depkes tahun 2001. ${ }^{3,4}$

Data yang dikumpulkan dari seluruh puskesmas yang berada di Kota Padang pada tahun 2011 menunjukkan bahwa penyakit infeksi saluran pernapasan akut (ISPA) menduduki peringkat teratas sepuluh penyakit terbanyak yaitu 115.361 atau sebesar 46,5\%. Presentase tahun 2011 naik dimana pada tahun 2010 kejadian ISPA hanya sebesar $43,57 \%$.,

Sampai saat ini, penatalaksanaan ISPA masih menggunakan metode empirik, biasanya dengan menggunakan antibiotika spektrum luas. Pemberian antibiotika empirik tentu saja tidak dapat diberikan terus-menerus, apalagi jika secara klinis pasien tidak membaik bahkan cenderung memburuk. Kotrimoksazol masih dijadikan pilihan pengobatan di pusat layanan primer. Kotrimoksazol dapat menghambat Staphylococcus aureus, Streptococcus hemoliticus, $H$. influenzae, bakteri Gram negatif aerob (E. coli dan Klebsiella sp.), dan Enterobacter. ${ }^{7-9}$

Penelitian Kumala et al. tahun 2010 di Laboratorium Mikrobiologi Klinik Fakultas Kedokteran Universitas Indonesia (LMK FK UI) periode Februari-April 2008 menunjukkan dari 124 sampel yang berasal dari sputum ditemukan Pseudomonas aeruginosa, Klebsiella pneumoniae dan juga Escherichia coli mengalami resistensi yang tinggi terhadap kotrimoksazol (64,24\%). Selain itu, penelitian Darlington et al. tahun 2010 yang dilakukan pada anak-anak di Zambia juga menemukan bahwa 59\% koloni spesimen dari S. pneumoniae dan 56\% koloni spesimen dari $H$. influenzae resisten terhadap kotrimoksazol. ${ }^{10,11}$ Oleh karena itu, diperlukan kajian berkala terhadap spektrum bakteri penyebab ISPA dan pola kepekaan isolat bakteri tersebut sehingga dapat membantu klinisi dalam menentukan antibiotika empirik sebelum hasil pemeriksaan mikrobiologi diperoleh.

\section{METODE PENELITIAN}

Jenis penelitian ini eksperimental laboratorium. Penelitian ini dilakukan di Poliklinik Paru RSUP Prof. Dr. R. D. Kandou, Manado pada bulan Oktober 2014 sampai dengan Januari 2015. Pemeriksaan sampel dilakukan di Laboratorium Mikrobiologi Fakultas Kedokteran Universitas Sam Ratulangi Manado dengan pewarnaan Gram terhadap 20 sampel.

\section{HASIL PENELITIAN}

Jumlah pasien ISPA di Poliklinik Paru RSUP Prof. Dr. R. D. Kandou Manado dari bulan November 2014 sampai dengan Januari 2015 yang bersedia menjadi responden penelitian sebanyak 20 pasien, kemudian dilakukan pengambilan sputum pada pagi hari sehingga diperoleh 20 sampel. Tabel 1 memperlihatkan distribusi responden berdasarkan jenis kelamin yaitu 15 orang laki-laki (75\%) dan 5 orang perempuan (25\%).

Tabel 1. Distribusi responden berdasarkan jenis kelamin

\begin{tabular}{ccc}
\hline Jenis kelamin & Frekuensi & $(\%)$ \\
\hline Laki-laki & 15 & 75,0 \\
Perempuan & 5 & 25,0 \\
Total & 20 & 100
\end{tabular}

Distribusi responden penelitian berdasarkan umur didapatkan yang terbnyk psda kelompok usia 51-60 tahun sebanyak 7 orang (35\%).

Tabel 2. Distribusi responden menurut umur

\begin{tabular}{ccc}
\hline $\begin{array}{c}\text { Umur } \\
\text { (tahun) }\end{array}$ & Frekuensi & $\mathbf{( \% )}$ \\
\hline $21-30$ & 1 & 5,0 \\
$31-40$ & 3 & 15,0 \\
$41-50$ & 5 & 25,0 \\
$51-60$ & 7 & 35,0 \\
$61-70$ & 4 & 20,0 \\
Total & 20 & 100 \\
\hline
\end{tabular}

Tabel 3 memperlihatkan distribusi pertumbuhan koloni. Adanya pertumbuhan 
pada media nutrien agar sebanyak 20 sampel, pada media Mac Conkey sebanyak 11 sampel, dan tidak ada pertumbuhan sebanyak 9 sampel.

Tabel 3. Distribusi sampel menurut pertumbuhan koloni

\begin{tabular}{lcc}
\hline \multicolumn{1}{c}{ Perbenihan } & $\begin{array}{c}\text { Nutrien } \\
\text { Agar }\end{array}$ & $\begin{array}{c}\text { Mac } \\
\text { Conkey }\end{array}$ \\
\hline $\begin{array}{l}\text { Ada } \\
\text { pertumbuhan }\end{array}$ & 20 & 11 \\
$\begin{array}{l}\text { Tidak ada } \\
\text { pertumbuhan } \\
\text { Total }\end{array}$ & - & 9 \\
\hline
\end{tabular}

Berdasarkan Tabel 4 terdapat bakteri Gram positif pada 12 sampel (60\%) dan bakteri Gram negatif pada 8 sampel (40\%).

Tabel 4. Distribusi sampel berdasarkan pewarnaan Gram

\begin{tabular}{ccc}
\hline $\begin{array}{c}\text { Pewarnaan } \\
\text { Gram }\end{array}$ & Frekuensi & $(\%)$ \\
\hline Positif & 12 & 60 \\
Negatif & 8 & 40 \\
Total & 20 & 100 \\
\hline
\end{tabular}

Tabel 5. Hasil biakan bakteri aerob dari sputum infeksi saluran pernapasan di Poliklinik Paru di RSUP Prof. Dr. R. D. Kandou Manado

\begin{tabular}{lcc}
\hline \multicolumn{1}{c}{ Bakteri Aerob } & Jumlah & $(\%)$ \\
\hline $\begin{array}{l}\text { Enterobacter } \\
\quad \text { chloacae }\end{array}$ & 1 & 5,0 \\
$\begin{array}{l}\text { Proteus } \\
\quad \text { alcalifaciens }\end{array}$ & 1 & 5,0 \\
$\quad$ Yersinia pestis & 1 & 5,0 \\
$\quad$ Enterobacter & 2 & 10,0 \\
$\quad$ agglomerans & & \\
$\quad \begin{array}{l}\text { Serratia } \\
\quad \text { marcescens }\end{array}$ & 1 & 5,0 \\
$\begin{array}{l}\text { Serratia rubidaea } \\
\text { Serratia }\end{array} \quad 1$ & 5,0 \\
$\quad$ liquefaciens & 1 & 5,0 \\
$\begin{array}{l}\text { Bacillus subtilis } \\
\text { Streptococcus sp. }\end{array}$ & 10 & 50,0 \\
$\quad$ Total & 2 & 10,0 \\
\hline
\end{tabular}

Tabel 5 menunjukkan bahwa terdapat 20 jenis bakteri pada sputum penderita ISPA yaitu: Enterobacter chloacae sebanyak 1 sampel (5\%), Proteus alcalifaciens sebanyak 1 sampel (5\%), Yersinia pestis sebanyak 1 sampel (5\%), Enterobacter agglomerans sebanyak 2 sampel (10\%), Serratia marcescens sebanyak 1 sampel (5\%), Serratia rubidaea sebanyak sat1u sampel (5\%), Serratia liquefaciens sebanyak 1 sampel (5\%), Bacillus subtilis sebanyak 10 sampel (50\%) dan Streptococcus sp. sebanyak 2 sampel (10\%).

\section{BAHASAN}

Distribusi responden berdasarkan jenis kelamin yaitu 15 orang laki-laki dan 5 orang perempuan. Hal tersebut sesuai dengan penelitian yang dilakukan di Nigeria dimana dari 1.539 penderita infeksi saluran pernapasan bawah ditemukan bahwa laki-laki lebih banyak dari pada perempuan yaitu sebanyak 841 penderita. Selain itu, hasil penelitian Panggalo et al. ${ }^{12}$ juga menunjukkan hal yang sama di mana pasien batuk berdahak didominasi oleh penderita laki-laki dengan jumlah 20 orang. Berdasarkan studi pada orang dewasa di Cina, risiko relatif laki-laki menderita infeksi saluran pernapasan terhadap perempuan ialah 2,80. Penelitian Kurniawati et al. $^{13}$ menunjukkan hasil pemeriksaan positif pada 27 dari 98 spesimen sputum (27\%) yang berasal dari 98 penderita tersangka tuberkulosis. Pada penelitian mengenai perbedaan sistem imun spesifik dan non spesifik berdasarkan jenis kelamin menunjukkan pada laki-laki terjadi peningkatan persentase. Hal ini dapat terjadi karena laki-laki lebih banyak melakukan kegiatan di luar rumah dan insidens merokok lebih sering pada lakilaki. $^{12-14}$

Distribusi sampel berdasarkan umur didapatkan umur 51-60 tahun merupakan kelompok umur terbanyak penderita ISPA. Hal itu dipengaruhi penurunan sistem imun yang terjadi pada usia lanjut.

Pada penelitian ini, dari 20 sampel yang diperiksa, distribusi pertumbuhan menunjukkan pada media nutrien agar terdapat pertumbuhan sebanyak 20 sampel, dan media Mac Conkey sebanyak 11 
sampel dan tidak ada pertumbuhan sebanyak 9 sampel (Tabel 3).

Tabel 4 menunjukkan hasil pewarnaan sampel di mana bakteri Gram positif sebanyak 12 sampel, sedangkan bakteri Gram negatif sebanyak 8 sampel. Hasil ini serupa dengan penelitian yang dilakukan Setiyanto et al. $^{15}$ di Rumah Sakit Persahabatan Jakarta tahun 2007 yang menemukan bakteri Gram positif (71,38\%) sebagai bakteri penyebab infeksi terbanyak, tetapi berbeda dengan hasil penelitian yang dilakukan oleh Marta et al. ${ }^{16}$ di RSUD Arifin Achmad Riau, yaitu bakteri Gram positif sebanyak 4 sampel, sedangkan bakteri Gram negatif sebanyak 19 sampel. Hal ini dapat disebabkan karena perbedaan waktu dan lokasi penelitian sehingga memberikan hasil yang berbeda pula.

Hasil koloni bakteri yang tumbuh dilakukan pewarnaan Gram dan kemudian dilakukan identifikasi dengan pemeriksaan secara mikroskopik dan dilanjutkan dengan uji biokimia. Pada uji biokimia ditemukan bakteri yang dapat menyebabkan infeksi saluran pernafasan yaitu Enterobacter chloacae 1 sampel (5\%), Proteus alcalifaciens 1 sampel (5\%), Yersinia pestis 1 sampel (5\%), Enterobacter agglomerans 2 sampel (10\%), Serratia marcescens 1 sampel (5\%), Serratia rubidaea 1 sampel (5\%), Serratia liquefaciens 1 sampel (5\%), Bacillus subtilis 10 sampel (50\%) dan Streptococcus sp. 2 sampel (10\%). ${ }^{19,20}$ Penelitian yang dilakukan Yuhamzi ${ }^{17}$ memperoleh hasil Staphylococcus koagulase negatif sebanyak 12 isolat (37,50\%), Streptococcus viridians sebanyak 9 isolat (28,12\%), Pseudomonas aeruginosa sebanyak 6 isolat (18,75\%), Klebsiella sp. 3 isolat $(9,37 \%)$, serta Streptococcus pyogenes dan Escherichia coli sebanyak 1 isolat (3,12\%). Penelitian oleh Setiyanto et al. ${ }^{15}$ di Rumah Sakit Persahabatan Jakarta tahun 2007 menemukan Streptococcus pyogenes sebesar 37,5\%, diikuti Streptococcus pneumonia 18,75\%, Streptococcus haemolyticus 15,63\%, Pseudomonas sp. 14,06\%, Klebsiella pneumonia 7,81\% dan Escherichia coli 6,25\%. Hasil penelitian yang diperoleh oleh Marta et al. ${ }^{16}$ yaitu bakteri Gram negatif ialah Klebsiella sp., Pseudomonas aeruginosa, Proteus mirabilis, sedangkan bakteri Gram positif ialah Streptococcus $\alpha$ hemolitycus, Streptococcus pneumoniae, Staphylococcus aureus, dan Staphylococcus epidermidis. Hasil penelitian yang diperoleh oleh peneliti (Tabel 5) memberikan gambaran adanya kesamaan dan perbedaan bakteri dengan masing-masing penelitian Yuhamsi, Setiyanto, dan Marta et al. ${ }^{15-17}$ Hal ini dapat disebabkan oleh pola kuman penyebab infeksi setiap lokasi atau daerah berbedabeda sehingga memberikan hasil pola kuman yang bervariasi juga.

\section{SIMPULAN}

Dari hasil penelitian dan bahasan dapat disimpulkan bahwa pemeriksaan bakteri pada 20 sampel penderita ISPA didapatkan pertumbuhan bakteri: Enterobacter chloacae, Proteus alcalifaciens, Yersinia pestis, Enterobacter agglomerans, Serratia marcescens, Serratia rubidaea, Serratia liquefaciens, Bacillus subtilis dan Streptococcus sp dengan bakteri penyebab tersering ialah Basillus subtilis.

\section{DAFTAR PUSTAKA}

1. Bibiana WL. Infeksi Saluran Pernafasan (1st ed). Jakarta: PT. Raja Grafindo Persada, 1994.

2. Bockemuhl J. Enterobacteriaceae. In: Burkhardt F, editor. Microbiologische Diagnostik. Stuttgart: Thieme, 1992; p. 141-5.; 1992

3. Brooks GF, Butel JS,Morse SA, Jawetz, Melnick, Adelberg. Mikrobiologi Kedokteran (23rd ed). Jakarta: EGC, 2007.

4. Brown A. Microbiological Applications Lab Manual (8th ed). NewYork: The McGraw-Hill Companies, 2001.

5. Ranuh IGG. Pendekatan Risiko Tinggi Dalam Pengelolaan Pelayanan Kesehatan Anak. Continuing Education Ilmu Kesehatan Anak. Surabaya: FK Unair, 1980.

6. Santosa G. Masalah Batuk pada Anak. Continuing Education Anak. Surabaya: FK Unair, 1980.

7. Gawat Darurat di Bidang Pulmonologi. 
Simposium Gawat Darurat pada Anak. Surabaya, 1987.

8. DepKes RI. Direktorat Jendral PPM \& PLP. Pedoman Pemberantasan Penyakit infeksi Saluran Pernapasan Akut (ISPA). Jakarta, 1992.

9. Bimbingan Ketrampilan dalam Penatalaksanaan Infeksi Saluran Pernapasan Akut Pada Anak. Jakarta, 1991; p. 10.

10. Lokakarya dan Rakernas Pemberantasan Penyakit Infeksi Saluran pernapasan akut. 1992.

11. Pendekatan Epidemiologi I dan Dasar-dasar Surveilens. Untuk Pelatihan Prajabatan Umum dan Khusus Tenaga Paramedis di Puskesmas. Jakarta. 1992.

12. Panggalo JT. Identifikasi bakteri aerob pada penderita batuk berdahak di poliklinik Interna BLU RSUP Prof. Dr. R. D. Kandou Manado [Skripsi]. Manado: Universitas Sam Ratulangi; 2013.

13. Kurniawati A, Risdiany E, Nilawati S, Prawoto, Rosana, Alisyahbana B, et al. Perbandingan Tan Thiam Hok, Ziel
Neelsen dan Fluorokrom sebagai metode pewarnaan Basil Tahan Asam untuk Pemeriksaan Mikroskopik Sputum. Makara Kesehatan. 2005;9(1):29-33.

14. Sartono, Sumarno. Gambaran pola kuman pada pemeriksaan Sputum di Rumah Sakit Umum Dr. Saiful Anwar Malang [unpublished]. 2002

15. Setiyanto $\mathbf{H}$, et al, Determinan Resistensi Bakteri terhadap Antibiotik pada Penyakit Paru Obstuktif Kronik Eksaserbasi Akut di Rumah Sakit Persahabatan Jakarta tahun 2007

16. Marta NA, Andrini F, Saad Azizman et al, Identifikasi Bakteri Pada Sputum Pasien Penyakit Paru Obstruktif kronis Eksaserbasi akut di RSUD Arifin Achmad, Riau. JOM FK. 2014;1(2).

17. Yuhamzi MO, Anggraini D, Zarfiardy AF. Pola Resistensi Bakteri dari Sputum Penderita Penyakit Paru Obstruktif Kronik (PPOK) Eksaserbasi bagian Paru RSUD Arifin Achmad Pekanbaru. Pekan Baru: Universitas Riau; 2012. Available from: repository.unri.ac.id. 